\title{
Improving Students' Writing Achievement Through Peer Review And Facebook For Grade XI of SMA Negeri 2 Singaraja
}

\author{
L.D.K. Lestari \\ English Education Department \\ Ganesha University of Education \\ Singaraja, Indonesia \\ e-mail: desikarunialestari@gmail.com
}

\begin{abstract}
This research aimed at improving students' writing achievement for grade $X$ in SMA Negeri 2 Singaraja through peer review and Facebook. In the planning step were carried out to create a Facebook group and make lesson plans. The results of the research showed as follows: First, there is a positive trend of the students' mean score. It increased from 64.9 in the pre test to 77.9 in the first cycle and to 88.7. Second, there were no students left behind in the second cycle. In pre test, there were 26 students who did not passed the passing grade of 72 . In the first cycle, the number decreased to 4 and finally all students' score had passed the passing grade after the second cycle. Third, the students' response toward the implementation of the technique is positive. This means that the third indicator of research success had also been accomplished.
\end{abstract}

Keywords: writing achievement, peer review, Facebook

\section{INTRODUCTION}

No one can deny the important roles played by English nowadays. It is one of the world languages used across the countries in world trading and business, education, science and technology, and many other aspects. It bridges the language diversity all over the world.

Since English is not the first language for all countries in the world, English needs to be taught either as a second language or foreign language. The difference between those two lies on the exposure of English in Malaysia. English is considered as a second language in Malaysia because it is frequently used in commercial, business, and even everyday life communication. There are many exposures of English in that country. Whereas in Indonesia, English is considered as foreign language because English is mainly used in the classroom. There is just little exposure of English in people's everyday life.

Teaching English in Indonesia involves teaching four skills of language namely listening, reading, speaking, and writing. According to Chitravelu, Choon, \&
Sithamparam (2005), the former two are called as receptive skills and the latter two are called as productive skills. These four skills are very essential to produce good communication.

There are two types of communication - spoken and written. Spoken communication involves listening, reading, and speaking competences. For instance, a conversation between two people employs listening and speaking skill and a father retelling a bedtime story to his little son may employ reading and speaking competences. Meanwhile, written communication involves listening, reading, and writing competences. The instance of there is someone taking a note while he is phoning someone and someone taking a note of a phone number while reading a phonebook.

Between these two types of communication, written communication is believed to be harder to do. Therefore, teaching writing is considered more difficult than teaching speaking or teaching receptive skills.

Why is writing so difficult to be done by students? Richards and Renandya 
(2002) point out that writing involves both lower cognitive thinking, such as the mastery of grammar, vocabulary and spelling, and higher order thinking such as developing ideas and organizing them into a text.

Unlike speaking, writing takes more time and process. According to Kamehameha School (2007), writing process consists of several steps namely Pre-writing, Drafting and Writing, Sharing and Responding, Revising and Editing, and Publishing. Pre-writing is planning out what is going to be written. The writing processes of pre-writing are getting ready to write, deciding on a topic, brainstorming and organizing ideas. Drafting is write and refine paragraphs and also focus on communication of meaning. Sharing and responding is share work to gain feedback. Revising and editing are revise content and text reorganization. Publishing is a finishing product students writing. These five steps may be fluid and overlapping.

The difficulty of writing is proved by the preliminary observation done in SMA Negeri 2 Singaraja. Writing was believed as the hardest skill among four skills in English. According to the interview with the teacher, the students had problems in developing ideas, organizing text, choosing appropriate words, using good grammars, and using good mechanics such as spelling and punctuation. The observation showed worse condition. The students were asked to write in a onetime process. They were asked to write and submit the text when they had finished. They did not have chances to look back at their text and do some revisions.

To confirm the result of the interview and observation, a pre test was administered. The result showed that most of the students did not pass the minimum passing grade of 72 . There were 26 students or $86.67 \%$ of the total number of the students who did not pass the minimum passing grade of 72 . There were only four students or $13.33 \%$ from the total number of the students who passed the minimum passing grade.

Since writing process is a hard job, students are not supposed to work on it on onetime process. Students should be given time through the writing stages. The techniques which can fit the process writing theory is peer review.

According to Farrell (2011), peer review is simply process of having a colleague review one's teaching and provide feedback. By giving feedback, students can interact to their friends to exchange their opinion or idea about their friends' writing.

However, the time allotment in the classroom is limited. It is more likely to be impossible doing a process writing in a limited time. One of the ways to make it possible is by using Facebook.

According to Yancey as cited in Bani-Hani (2014) Facebook can link between formal classroom writing and the use of the language learned outside of the classroom in informal communication. Thus, the discussion can be done outside classroom. To be done, it can be helped by the use of technology so that there will be no time or place limitation.

Peer review can take advantage of time freedom offered by Facebook. According to Yunus and Salehi (2012), Peer review happens on Facebook in which students are able to receive comments or responses to what they have posted at a fast pace.

In facilitating the process of Peer Review over Facebook, teacher only acts as an administrator and the main authority to control the discussion. The students can get feedback from teacher, also their friends, depends on whom they share their writing with.

From the explanation above, this research was focused on improving students' writing achievement through Peer Review and Facebook for grade XI in SMA Negeri 2 Singaraja.

\section{RESEARCH METHOD}

This research was designed in the form of action-based research. The subject of the study was the students of SMA Negeri 2 Singaraja, particularly the member of class XI IBB in the fourth semester of the academic year of $2014 / 2015$. The class consisted of 30 students. They were chosen based on the 
preliminary observation and interview with the English teacher of the school that showed the students' problem in writing.

The data of the study was collected from each cycle in which every cycle contains four stages, such as, planning, action, observation, and reflection. The first action was given after the pre-test was administered. The process of data collection of the pre-test was developed for the purpose of examining the prior achievement of the students in writing. The pre-test was carried out by asking students to write an analytical exposition text. Based on the pretest result that was given to the students, the cyclic procedure were prepared to solve the problem faced by students. The procedures of the first cycle were as follows:

1. Planning

In this stage, some things which were prepared:

a. Creating Facebook accounts to anticipate the students who were not skillful in using technology.

b. Selecting the teaching materials that were applied during the action stage.

c. Preparing teaching scenario that was used for the consideration in conducting the action.

d. Preparing the instruments that were needed such as researcher's diary, observation checklists, questionnaire, and preparing rubric of writing skills for assessing the final revised of students' writing.

e. Preparing research aids such as computers, internet connection, and so forth.

\section{Action,}

There were two types of actions done in this stage. The first action was done in the classroom and the second action was done through the use of Facebook.

\section{Observation and evaluation}

The observation was done by filling the observation checklists in order to know the participation of the students in doing peer review. The points that were observed have been listed in the instrument. Finally, after the students posted the revised version of their writing, the writings were assessed by using the decided rubric (also see instrument).

\section{Reflection}

According to the result of observation, the conclusion could be withdrawn as well as the weaknesses and strengths of peer review and Facebook. In addition, the result of the observation could also become an indicator whether the cycle would be continued or stopped.

The reflection of the first cycle contributed to the decision of planning in the second cycle. In the second cycle, this cycle was much alike with the first cycle. The procedures were as follows:

1. Planning

In this stage, some things which were prepared:

a. Selecting the teaching materials that were applied during the action stage.

b. Preparing teaching scenario that was used for the consideration in conducting the action.

c. Preparing the instruments that were needed such as researcher's diary, observation checklists, questionnaire, and preparing rubric of writing skills for assessing the final revised of students' writing.

d. Preparing research aids such as computers, internet connection, and so forth.

\section{Action}

There were two types of actions done in this stage. The first action was done in the classroom and the second action was done through the use of Facebook.

3. Observation and evaluation

The observation was done by filling the observation checklists in order to know the participation of the students in doing peer review. The points that were observed have been listed in the instrument. Finally, after the students posted the revised version of their writing, the writings were assessed by using the decided rubric (also see instrument).

4. Reflection

According to the result of observation, the conclusion could be withdrawn as well as the weaknesses and strengths of peer review and Facebook. In addition, the result of the observation 
could also become an indicator whether the cycle would be continued or stopped.

In order to collect data during the research, the researcher prepared some means for collecting data called instruments. The instruments prepared by the researcher were researcher's diary, observational checklists, questionnaire, and rubric of writing skills.

In the second cycle, the different might be on the different theme or topic of the students' text. It was said to be successful in improving students writing achievement at grade XI IBB of SMA Negeri 2 Singaraja if the students' mean score increased from pre-test, post test 1 and post test 2, and also all the students' scores were above the passing grade of 72. And most of the students considered the use of peer review and Facebook very helpful for them in writing an analytical text.

\section{FINDINGS AND DISCUSSION}

There were two types of data in this research: quantitative in form of test result and qualitative in form of questionnaire result. The findings were presented based on the result in preliminary observation, cycle I, and cycle II.

In preliminary observation there were three kinds of techniques used to get the overview of the problems in writing class namely classroom observation, teacher interview, and pretest.

The result of the classroom observations showed that the writing process went on in a onetime process. First, students were given an example of the text. They discussed about the text and finally learned about the text concept. When the students understood the concept, they were asked to write a text individually. When the students finished writing the texts, the teacher submitted them to be assessed. In reflection to process writing theory, this seemed to be a problem. According to process writing theory, there were several steps which should be undergone by students in order to produce better texts. The steps were planning, drafting, revising, editing, and publishing. Therefore, the ideal writing class should involve these processes.

The interview with the teacher was conducted soon after the teaching and learning process. The teacher stated that writing was indeed the hardest skill of four skills for her students. According to her, the students found it difficult in developing ideas, organizing texts, choosing appropriate words, using good grammar, and using appropriate mechanics. When the students were asked to write a text, they found it difficult to develop their ideas. They wrote only few sentences which were sometimes organized randomly. They also had problems in vocabulary mastery. They had only few vocabularies on their mind so that it was difficult for them to choose appropriate words which affected the quality of the text. It's even getting worse when they used bad grammars and misused the mechanics such as spelling and punctuation. Therefore, when students worked individually, they felt more difficult in producing good quality of text. Another problem is the time allotment was very limited. They had only 90 minutes in the classroom. It seemed impossible to do the five stages of process writing in the classroom. Therefore, the use of Facebook was proposed in this research to overcome this time limitation problem.

Pretest was administered to reconfirm the problem which was going to deal with in this research. The pretest was conducted by asking students to write an analytical exposition text about the effect of smoking. There were thirty students taking the pre test. They collected a total score of 1947 and a mean score of 64.9. The result of the pretest is shown by the following table. 
Table 1. The result of pre test

\begin{tabular}{rrrr}
\hline $\begin{array}{l}\text { Success } \\
\text { indicator }\end{array}$ & $\begin{array}{l}\text { Number of } \\
\text { students }\end{array}$ & Percentage (\%) & Category \\
\hline $\mathbf{2 7 2}$ & 4 & 13.33 & No Problem \\
\hline$\leq 72$ & 26 & 86.67 & Have Problem \\
\hline
\end{tabular}

This finding indicated that writing was a very serious problem for almost all students. Among 30 students taking the pre test, there were only four students or approximately $13.33 \%$ of the whole number of students who passed the minimum passing grade of 72 . Meanwhile, there were 26 students or approximately $86.67 \%$ of the total number of students who did not pass the minimum passing grade of 72 .

Based on this preliminary data, it was considered important to find an effective way which (1) overcame the problem of time limitation and (2) implemented the process of writing. The time limitation could be overcome by the use of Facebook and the process of writing could be implemented by giving the chances for students to do peer review.

It was considered important to find an effective way to improve students' writing achievement. Cycle 1 was carried out following four steps of classroom action research namely planning, action, observation and evaluation, and reflection.

The planning stages involve (1) creating a Facebook group, and (2) developing lesson plans. In creating a Facebook groups, it was created to facilitate the process of peer review. The group was named XI Bahasa Smanda. XI indicates the grade of students; Bahasa indicates their specialization on language; and SMANDA is an abbreviation of SMA Negeri 2 Singaraja. The group was set up secret for some reasons such as (1) preventing unanticipated users to join, and (2) keeping the discussing from being public so that student feel secured. After the group was ready, the students' Facebook were collected and invited into the group. It took a few days to have all the students' Facebook in the group. After a consultation with the English teacher in that class, it was known that the material left was Analytical Exposition Text. It was just right with the aimed of the research to improve students' writing competency. The first thing to do was developing several indicators based on core competency and basic competency.

In the action, there were three sessions carried out in the first cycle. Each of the session consisted of a classroom meeting and an online meeting. In the first cycle, students were given a topic to write. The topic was "Is smoking good for us?". In the first meeting, students focused on the social function and text structure. In the second meeting, students focus on the language features of analytical exposition text. And in the third meeting the students were asked to do final revision and editing. They were asked to revise based on the comments and in the online meeting, the students uploaded their final texts.

After finishing cycle 1, the assessment was made on the final works of the students. Referring to the writing rubric, there are five components taken into account namely content, organization, grammar, vocabulary, and mechanic. Same as pre test, there were 30 students taking part in the first cycle. The assessment of the students' final revision of text produced a total score of 2339 and a mean score of 77.9. The result of the post test one is shown in the table. 2 below. 
Table 2. The result of post test I

\begin{tabular}{rccl}
\hline $\begin{array}{r}\text { Success } \\
\text { indicator }\end{array}$ & $\begin{array}{c}\text { Number of } \\
\text { students }\end{array}$ & $\begin{array}{c}\text { Percentage } \\
(\%)\end{array}$ & Category \\
\hline $\mathbf{7 2}$ & 26 & 86.67 & No Problem \\
\hline$\leq 72$ & 4 & 13.33 & Have Problem \\
\hline
\end{tabular}

This finding shows that writing was still a problem for a few students. Among 30 students taking the pre test, there were twenty six students or approximately $86.67 \%$ of the whole number of students who passed the minimum passing grade of 72. Meanwhile, there were 4 students or approximately $13.33 \%$ of the total number of students who did not pass the minimum passing grade of 72 .

Similar with the first cycle, there were three sessions carried out in the second cycle. There were 30 students taking part in the second cycle. After that the students were given a topic to write. The topic was "Mobile phone should be banned at school". In the fourth meeting, students focused on the social function and text structure. In the fifth meeting, students focus on the language features of analytical exposition text. And in the sixth meeting the students were asked to do final revision and editing. They were asked to revise based on the comments and in the online meeting, the students uploaded their final texts.

After finishing cycle 2, the assessment was made on the final works of the students. Referring to the writing rubric, there are five components taken into account namely content, organization, grammar, vocabulary, and mechanic. The assessment of the students' final text had a total score of 2426 and a mean score of 80.87. The result of the post test II is shown in the table.3 below.

Table 3. The result of post test II

\begin{tabular}{cccc}
\hline $\begin{array}{c}\text { Success } \\
\text { indicator }\end{array}$ & $\begin{array}{c}\text { Number of } \\
\text { students }\end{array}$ & $\begin{array}{c}\text { Percentage } \\
(\%)\end{array}$ & Category \\
\hline$\geq 72$ & 30 & 100 & $\begin{array}{c}\text { No } \\
\text { Problem }\end{array}$ \\
\hline $\mathbf{5 7 2}$ & 0 & 0 & $\begin{array}{c}\text { Have } \\
\text { Problem }\end{array}$ \\
\hline
\end{tabular}

This finding shows that writing had no longer become a problem for the students. Among 30 students taking part in the cycle II, there were all students or $100 \%$ of the total number of students who passed the minimum passing grade of 72 . This means that no students or $0 \%$ of students had got score below the minimum passing grade of 72 .
An indicator of research success is to have all the students' score above the passing grade. To see whether or not all students have passed the passing grade, it is important to have a closer look at each of their score individually. The following table. 4 shows the number of students who have and have not passed the passing grade.

Table 4. The number of students achieving the passing grade from the pretest - post test II

\begin{tabular}{|c|c|c|c|c|c|c|}
\hline \multirow{2}{*}{$\begin{array}{l}\text { Success } \\
\text { indicator }\end{array}$} & \multicolumn{2}{|c|}{ Pre test } & \multicolumn{2}{|c|}{ Post Test I } & \multicolumn{2}{|c|}{ Post Test II } \\
\hline & $\begin{array}{l}\text { Number } \\
\text { of } \\
\text { students }\end{array}$ & $(\%)$ & $\begin{array}{l}\text { Number } \\
\text { of } \\
\text { students }\end{array}$ & $(\%)$ & $\begin{array}{l}\text { Number } \\
\text { of } \\
\text { students }\end{array}$ & $(\%)$ \\
\hline$\geq 72$ & 4 & $13.33 \%$ & 26 & $86.67 \%$ & 30 & $100 \%$ \\
\hline$\leq 72$ & 26 & $86.67 \%$ & 4 & $13.33 \%$ & 0 & 0 \\
\hline
\end{tabular}


In pretest, there were only four students who had passed the passing grade of 72 . Most of them, around 26 students, got score below the passing grade of 72. After the implementation of the technique in the first cycle, the students' writing competency got better. The first posttest shows that there were 26 students who had passed the passing grade. Four students were still under the expected passing grade. This means that the implementation of the technique had not been successful yet. However, the second post test shows that all students had been above the passing grade. No one left behind which meant the target indicators has already been achieved. The technique has already given a significant effect to improve students' writing achievement.

In the cycle II, besides giving a test, a questionnaire was also spread to the students to obtain data about students' response toward the use of peer review and Facebook in improving their writing achievement. The questionnaire consisted of seven close-ended questions. There are four responses available. The responses varied from very helpful to not helpful.

The first question was whether the use of peer review and Facebook could help them in writing an analytical exposition text. The result shows that there were about twenty students or about $66.67 \%$ of the total number of the students felt that the use of peer review and Facebook was very helpful for them in writing an analytical exposition text. There were about eight students or $26.67 \%$ of the students who taught that the technique was helpful and there were only two students or about $6.67 \%$ of the students who considered the technique less helpful in writing an analytical exposition text. The graphic. 1 below illustrates the students' response on item no 1.

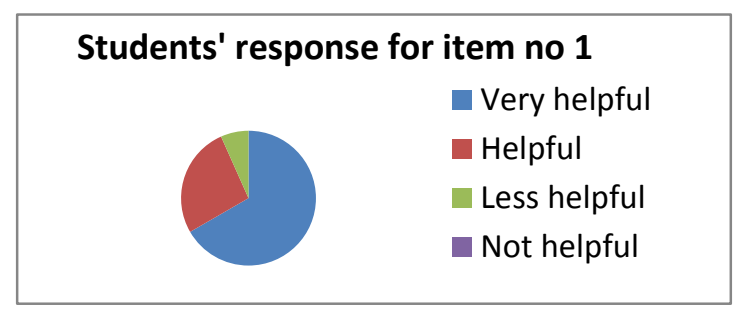

Graphic. 1 the students' response on question item no 1.

The second question was whether or not the peer review and Facebook could help them in developing ideas. Then it was found that there were 19 students or about $63.33 \%$ of students felt that the use of peer review and Facebook was very helpful. Meanwhile, it was also helpful for five students or $16.67 \%$ of the students and less helpful for six students or about $20 \%$ of the total number of the students. The graphic.2 below illustrates the students' response on item no 2.

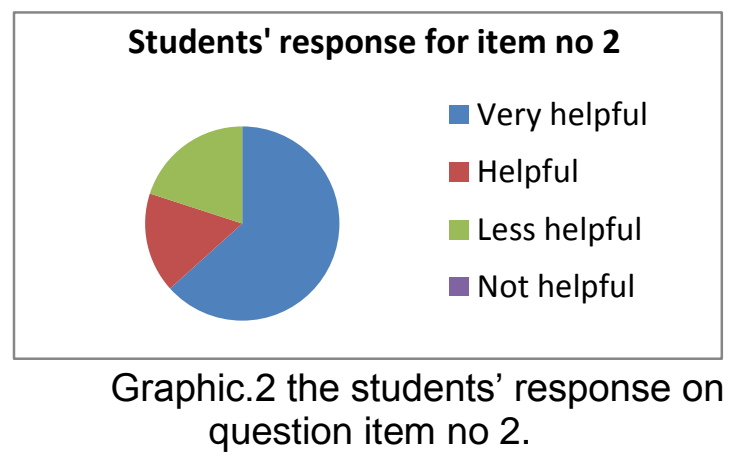

The third question was asking whether the use of peer review and Facebook could help the students to organize the paragraphs. The result found that there were 19 students or about $63.33 \%$ of students considered that the use of review and Facebook was very helpful for them in organizing paragraphs. Meanwhile, seven students or about $23.33 \%$ of the students felt that the technique was helpful and four students or about $13.33 \%$ of the students felt that the technique was less helpful for them. The graphic.3 below illustrates the students' response on item no 3. 


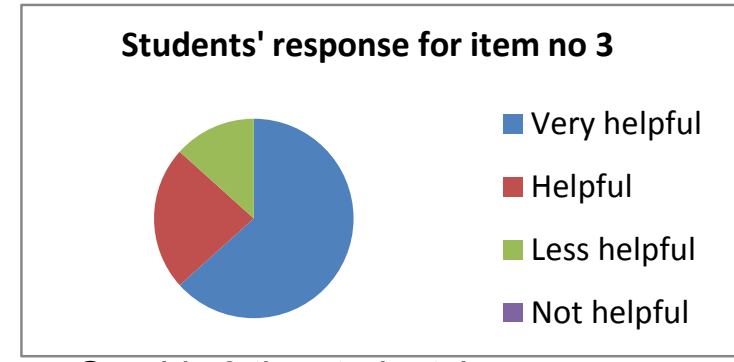

Graphic.3 the students' response on question item no 3.

The fourth question was asking whether the use of peer review and Facebook could help the students in choosing the appropriate words. It was found that there were 22 students or about $73.33 \%$ of students considered that the use of review and Facebook was very helpful for them to choose the appropriate words. Meanwhile, seven students or about $23.33 \%$ of the students felt that the technique was helpful and one student or about $3.33 \%$ of the students felt that the technique was less helpful for them. The graphic. 4 below illustrates the students' response on item no 4.

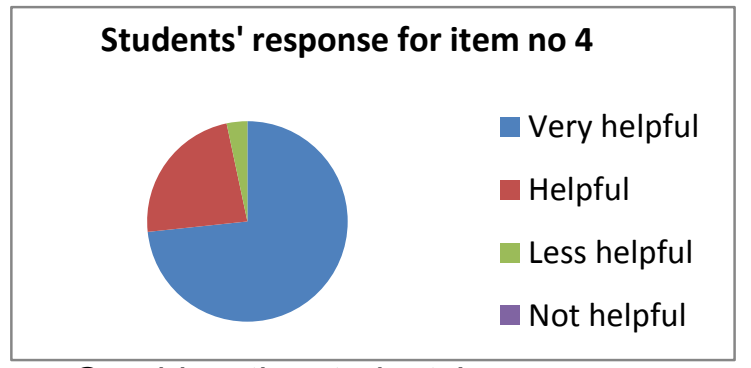

Graphic.4 the students' response on question item no 4.

The fifth question was asking whether the use of peer review and Facebook could help the students to deal with mechanics such as spelling and punctuation. The result found that there were 15 students or about $50 \%$ of students considered that the use of review and Facebook was very helpful for them in dealing with spelling and punctuation. Meanwhile, the half or about 15 students felt that the technique was helpful for them. The graphic. 5 below illustrates the students' response on item no 5.

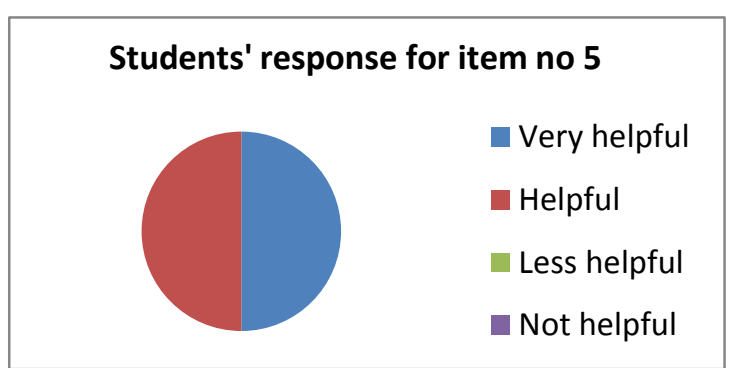

Graphic.5 the students' response on question item no 5.

The sixth question was asking whether the use of peer review and Facebook could help the students to use good grammars. It was found that there were 23 students or about $76.67 \%$ of students considered that the use of review and Facebook was very helpful for them in using good grammars. Meanwhile, five students or about $16.67 \%$ of the students felt that the technique was helpful and two students or about $6.67 \%$ of the students felt that the technique was less helpful for them. The graphic. 6 below illustrates the students' response on item no 6.

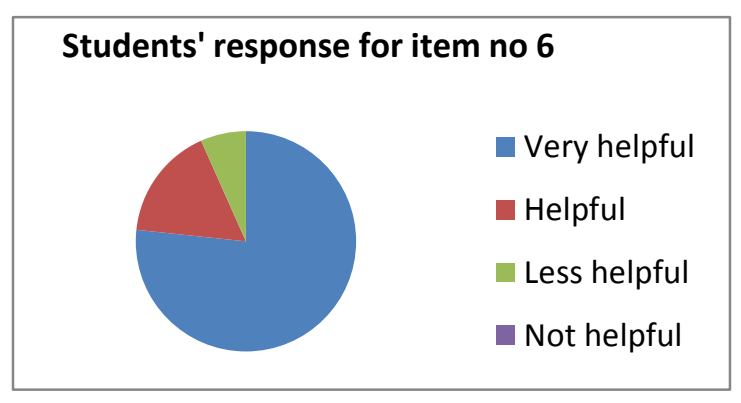

Graphic. 6 the students' response on question item no 6

The last question was asking whether the use of peer review and Facebook could help motivating the students to write a text. It was found that there were 25 students or about $83.33 \%$ of students considered that the use of review and Facebook was very helpful and motivating in writing a text. Meanwhile, five students or about $16.67 \%$ of the students felt that the technique was helpful and motivating enough for them to write a text. The graphic.7 below illustrates the students' response on item no 7. 


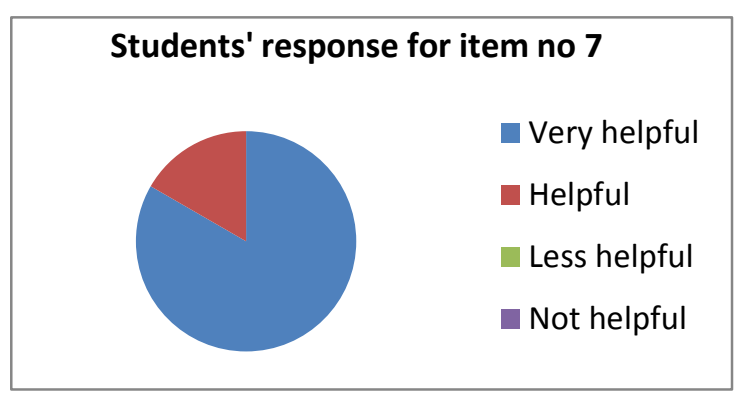

Graphic.7 the students' response on question item no 7.
The result of students' response shows that there were more than half $(\geq$ $50 \%$ ) of the students considered the use of peer review and Facebook was at very helpful for them in developing ideas, organizing paragraphs, choosing appropriate vocabularies, using good grammars, and using appropriate spelling and punctuation. They also felt motivated with the use of peer review and Facebook. The result of the questionnaires is shown in the following table. 5 below.

Table. 5 the summary of questionnaire result

\begin{tabular}{ccccc}
\hline Item No & $\begin{array}{c}\text { Very } \\
\text { Helpful }\end{array}$ & Helpful & $\begin{array}{c}\text { Less } \\
\text { Helpful }\end{array}$ & $\begin{array}{c}\text { Not } \\
\text { Helpful }\end{array}$ \\
\hline $\mathbf{1}$ & 20 & 8 & 2 & 0 \\
\hline $\mathbf{2}$ & 19 & 5 & 6 & 0 \\
\hline $\mathbf{3}$ & 19 & 7 & 4 & 0 \\
\hline $\mathbf{4}$ & 22 & 7 & 1 & 0 \\
\hline $\mathbf{5}$ & 15 & 15 & 0 & 0 \\
\hline $\mathbf{6}$ & 23 & 5 & 2 & 0 \\
\hline $\mathbf{7}$ & 25 & 5 & 0 & 0 \\
\hline Average & 20.4 & 7.4 & 2.2 & 0 \\
\hline $\begin{array}{l}\text { Percentage of the } \\
\text { average number of } \\
\text { students }\end{array}$ & $68 \%$ & $24.67 \%$ & $7.33 \%$ & $0 \%$ \\
\hline
\end{tabular}

The table. 5 indicates the summary of students' response. It was found out that averagely about $68 \%$ of the total number of students considered that the use of peer review and Facebook was very useful for them in developing ideas, organizing paragraphs, choosing appropriate vocabularies, using good grammars, and using good mechanics. On the other hands, there were only $24.67 \%$ of the total number of students who considered that the use of peer review and Facebook was helpful for them in developing ideas, organizing paragraphs, choosing appropriate vocabularies, using good grammars, and using good mechanics. The rest, about $7.33 \%$ students considered that the use of peer review and Facebook was less helpful for them in developing ideas, organizing paragraphs, choosing appropriate vocabularies, using good grammars, and using good mechanics.
Because of all the success indicators had already been achieved, the research was stopped in the second cycle. It is found that Peer Review and Facebook could improve the students' writing achievement at grade XI of SMA Negeri 2 Singaraja.

\section{CONCLUSION AND SUGGESTION}

This classroom action research was conducted in two cycles. Each cycle consisted of planning, action, observation and evaluation, and reflection. Each of the action consisted of three sessions and took place in a classroom and in the Facebook group.

The first and second cycle started by creating a Facebook group and designing a lesson plan. Then, the lesson plan was carried out into action. In the classroom, the students learned about the concept of analytical exposition, and wrote and revised their draft of text. In the Facebook group, the students posted their draft, 
commented on their friends' posts and uploaded the final version of the text. After the cycles finished, an evaluation to each cycle was conducted.

In the first cycle, an evaluation was done on the students' final version of text. The evaluation in the first cycle shows that there were 30 students taking part in the post test. Their total score 2339 and the mean score was 77.9. Among 30 students, there had been 26 students who passed the minimum passing grade. But, there were still four students who had not passed the minimum passing grade. This means that the success indicator had not been successfully accomplished yet.

Therefore, the research continued to cycle II. Meanwhile, there were two kinds of evaluation in cycle II. The first one was made on the students' final version of text (post test II). Same as in the cycle I, there were 30 students taking part in the post test. Their total score 2426 and the mean score was 80.87. This mean score improved from the first cycle. Among 30 students, all students had passed the minimum passing grade. No students were reported having scores lower than 72 . This means that the success indicator had been successfully accomplished in the cycle II. Therefore, the research stopped in this cycle. The questionnaire showed that about $68 \%$ of students felt that the use of peer review and Facebook was very helpful; $26.67 \%$ of students felt that it was helpful; and $7.33 \%$ of students felt that it was less helpful to develop ideas, organize paragraphs, choosing appropriate vocabularies, using good grammars, and using good mechanics.

It could be concluded that Peer Review and Facebook could improve the students' writing achievement at grade XI of SMA Negeri 2 Singaraja.

Based on these result, the researcher suggests for the teacher that learning does not always have to happen in the classroom. Teacher can utilize technology such as Facebook to improve their teaching quality. Therefore, they need to start introducing technology to their students. And the implementation of peer review indicates the less dominance of teacher in the classroom. Teacher does not always have to lead them to learn. Therefore, teacher can use peer review in other topics or subject matters to create a student-centered learning and the teacher can use this technique to improve their students' writing competency.

\section{REFERENCES}

Bani-Hani, N. A., Al-Sobh, M. A., \& AbuMelhim, A.H (2014). Utilizing Facebook groups in teaching writing: Jordanian EFL students' perceptions and attitudes. International Journal of English Linguistics, 4(5). doi:10.5539/ijel.v4n5p27

Chitravelu, N., Sithamparam, S., \& Choon, T. S. (2005). ELT methodology: principles and practice. Selangor: Oxford Fajar Sdn. Bhd. 